338.91

\title{
- ністрянськ
}

ьвівський н ціон льний університет імені в н вул. . орошенк , 41, м. ьвів, 79000, кр їн

бгрунтов но методику н лізу суспільно-геогр фічної ролі селищ у соці льному обслуговув нні сільської місцевості. креслено демогр фічні контури сфери впливу селищ ьвівської обл. н сільську місцевість т про н лізов но функціон льні можливості селищ у суспільно-геогр фічному спекті.

лючові слов : селищ міського типу, сільськ місцевість, соці льне обслуговув ння, демогр фічний потенці л селищ.

елищ міського типу, як і міст , виконув ли і виконують різнобічні соці льно-економічні функції (промислові, рекре ційні, тр нспортні). дн к, порівняно з міст ми, їхнє місце в системі економіко-геогр фічних відносин є незн чним, воно лише ч стково розкрив є сукупний суспільно-геогр фічний потенці л цієї к тегорії поселень. отже, основне функціон льне зн чення селищ поляг $є$ у викон нні в жливої функції щодо обслуговув ння сільської місцевості, тобто з безпечення т ких первинних соці льних потреб н селення сусідніх сіл (освітніх, лікув льних, тр нспортних, торгових, культурних), яких вони не можуть одерж ти у своїх поселеннях. е лізуючи відповідні послуги, селищ сприяють зміцненню мережі сільських поселень з г лом.

роблем орг нізув льної ролі селищ у сільській місцевості в н уковій літер турі відобр жен лише побіжно, зокрем , у контексті викон ння функцій центрів обслуговув ння всім міськими поселеннями, що свого ч су було широко відобр жене у теорії центр льних місць. томість безпосереднє зн чення селищної мережі в систем х розселення кр їни н лізув ло неб г то н уковців, зокрем , . ж м н [1], . оценко [2], . в рік [3], кцентуючи ув гу н с мперед н т ких спект х, як демогр фічний т економічний потенці ли селищ. одноч с пит ння зн чущості селищ в обслуговув нні сільської місцевості в укр їнській суспільно-геогр фічній літер турі висвітлені ще недост тньо.

ропонов н методологія дослідження цієї проблеми передб ч є: 1) н ліз функцій усієї селищної мережі в обслуговув нні сільських поселень, як д є змогу виділити, зокрем, великі території з недост тністю центрів первинного соці льного обслуговув ння сільської місцевості; 2) визн чення можливостей кожного селищ в н д нні соці льних функцій сільським поселенням.

методиці оцінки функціон льних можливостей усіх селищ регіону в обслуговув нні сільської місцевості виходимо з того, що цей пок зник (сукупний рівень зн чущості селищної мережі для сільської місцевості ( $c$ м) є прямо пропорційним до щільності селищ ( c) т щільності сільського н селення ( $c$ н) т обернено пропорційний до

(C) ністрянськ ., 2012 
щільності міст ( $\mathrm{M}$ ), дже 3 н явності мережі міст с ме вони ст ють основними центр ми обслуговув ння сільської місцевості.

визн ченні функціон льного потенці лу кожного селищ в з безпеченні потреб первинного рівня треб виділити н с мперед коло сільських поселень, які н йближче розміщені с ме до цього міського поселення в меж х певного дміністр тивного р йону, визн ч ючи і кількість с мих сільських поселень, і кількість сільського н селення, які безпосередньо тяжіють до цього селищ . обто н йбільший р діус впливу селище м тиме у тому вип дку, якщо в геогр фічній близькості до нього нем є міст. жливо з зн чити, що орг ніз ційний вплив селищ стосується н с мперед сіл відповідного дміністр тивного $\mathrm{p}$ йону, дже в $\mathrm{p}$ зі обслуговув ння мешк нців інших $\mathrm{p}$ йонів у деяких уст нов х (школи, лік рні) можуть виник ти дміністр тивні перешкоди. тже, функціон льно зн чущими є ті селищ, які розміщені у місцевості з високою густотою сільського н селення, н території якої нем є міст. одноч с якість викон ння селищем функцій центру обслуговув ння з лежить від т ких вз ємопов'яз них чинників, як геогр фічне положення, демогр фічний т інфр структурний потенці л. обто селище м тиме дост тньо з собів впливу н прилеглу сільську місцевість, якщо воно м $є$ доволі зн чні демогр фічні п р метри і вигідне тр нспортно-геогр фічне положення, т водноч с у цьому селищі є т кі інфр структурні об'єкти, які м ють притяг льне зн чення для різних соці льних груп сільського н селення ( дміністр тивні структури (це стосується селищ - p йонних центрів), з лізничн ст нція, втост нція, лік рня, середні спеці льні н вч льні з кл ди, промислові об'єкти). тже, зн чущість селищ у викон нні орг ніз ційно-обслуговчих функцій зрост $\epsilon$, якщо поряд нем є інших міських поселень. контексті геогр фічного положення ще р 3 н голосимо, що функціон льн зн чущість селищ 3 лежить від середнього р діус його впливу н сільську місцевість і від з селеності цієї місцевості. одноч с зіст влення р діус впливу селищ н сільську місцевість 3 його демогр фічним т інфр структурним потенці л ми д $є$ підст ви для висновків про ефективність викон ння селищем функції орг ніз ційного центру в сільській місцевості.

озр хунки сукупного рівня зн чущості селищної мережі для сільської місцевості (т бл. 1), викон ні з з пропонов ною методикою н підст ві використ ння офіційних д них ерж вної служби ст тистики кр їн, д ли змогу виявити регіон льні відмінності ст ну т перспектив соці льного обслуговув ння селищ ми сільської місцевості, об'єктивність і достовірність яких підтверджен іншими суспільно-геогр фічними ф кт ми. прикл д, незв ж ючи н те, що щільність селищ у т ких індустрі льно розвинутих регіон х, як онецьк т уг нськ обл сті, є н йбільшою, їхній сукупний рівень зн чушості в обслуговув нні сільського н селення зн чно менші, ніж у середньому по кр їні, оскільки в цих регіон х низьк щільність сільського н селення і сільських поселень т висок щільність міст, які м ють більші перев ги в обслуговув нні сільських поселень через з г лом вищий демогр фічний т інфр структурний потенці л.

йвищий рівень соці льно-орг ніз ційної зн чущості селищ виявляється у двох 3 хідних обл стях ( к рп тській т в но- $\mathrm{p}$ нківській), т кож в рим. е зумовлено тим, що для рик рп ття т к рп ття х р ктерн особливо висок щільність сільського н селення з н явності дост тньо розг луженої селищної мережі, як 3 т ких умов н був є в жливого функціон льного зн чення н віть 3 ур хув нням дещо вищої, ніж у середньому по кр їні, густоти міст. собливо це помітно в гірській місцевості, де с ме селищ є головними міськими центр ми соці льного обслуговув ння сільської місцевості. елик щільність селищ зумовлює і високий рівень їхнього зн - 
чення як орг ніз ційних центрів у сільській місцевості рим, особливо у степових p йон х, де селищ головно і виконують функції р йонних центрів.

блиця 1

егіон льні відмінності розміщення селищ міського типу кр їни т їхнього впливун н сільську місцевість

\begin{tabular}{|c|c|c|c|c|}
\hline $\begin{array}{c}\text { кр їн , втономія, } \\
\text { обл сті }\end{array}$ & $\begin{array}{c}\text { ільність } \\
\text { смт, кількість } \\
\text { н тис. км² }\end{array}$ & $\begin{array}{c}\text { ільність } \\
\text { міст, кількість } \\
\text { нис. км² }\end{array}$ & $\begin{array}{c}\text { ільність } \\
\text { сільського } \\
\text { н селення, } \\
\text { осіб н км }\end{array}$ & $\begin{array}{c}\text { укупний рівень } \\
\text { зн чущості селищної } \\
\text { мережі для сільської } \\
\text { місцевості }\end{array}$ \\
\hline кр їн & 1,47 & 0.76 & 23,73 & 45,90 \\
\hline рим & 2,15 & 0.61 & 27,96 & 98,07 \\
\hline інницьк & 1,09 & 0,68 & 31,15 & 49,93 \\
\hline олинськ & 1,09 & 0,55 & 24,89 & 49,33 \\
\hline ніпропетровськ & 1,44 & 0,63 & 17,27 & 39,47 \\
\hline онецьк & 4,94 & 1,96 & 15,82 & 39,87 \\
\hline итомирськ & 1,44 & 0,37 & 17,96 & 69,90 \\
\hline к рп тськ & 1,48 & 0,86 & 61,25 & 105,41 \\
\hline порізьк & 0,81 & 0,51 & 15,27 & 24,25 \\
\hline в но- р нківськ & 1,73 & 1,08 & 56,32 & 90,22 \\
\hline иївськ & 1,07 & 0,90 & 22,95 & 27,29 \\
\hline іровогр дськ & 1,10 & 0,49 & 15,59 & 34,93 \\
\hline уг нськ & 4.08 & 1,39 & 11,39 & 33,43 \\
\hline ьвівськ & 1,38 & 2,02 & 45,77 & 31,27 \\
\hline икол ївськ & 0,69 & 0,37 & 15,53 & 28,96 \\
\hline деськ & 0,99 & 0,57 & 23,85 & 41,42 \\
\hline олт вськ & 0,73 & 0,52 & 20,07 & 28,18 \\
\hline івненськ & 0,80 & 0,55 & 29,97 & 43,59 \\
\hline умськ & 0,84 & 0,63 & 15,86 & 21,15 \\
\hline ернопільськ & 1,23 & 1,30 & 44,1 & 41,73 \\
\hline рківськ & 1,94 & 0,54 & 17,48 & 62,8 \\
\hline ерсонськ & 1,05 & 0,32 & 14,83 & 49,28 \\
\hline мельницьк & 1,17 & 0,63 & 29,03 & 53,91 \\
\hline ерк ськ & 0,72 & 0,77 & 26.96 & 25.21 \\
\hline ернівецьк & 0.99 & 1,36 & 64,57 & 47,00 \\
\hline ернігівськ & 0,91 & 0,50 & 12,76 & 23,22 \\
\hline
\end{tabular}

н чно нижч, ніж у середньому по кр їні, щільність міст у итомирській т рківській обл стях і водноч с з тим висок концентр ція селищ (у рківській обл. 61, итомирській - 43) визн чили і їхній дост тньо високий, порівняно з іншими регіон ми, рівень впливу н сільську місцевість. омітн роль селищ для обслуговув ння сільської місцевості виявляється т кож у інницькій, олинській, ерсонській т мельницькій обл стях, де щільність міст зн чно менш від щільності селищ.

езв ж ючи н н явність у ьвівській обл. кількісно зн чної селищної мережі (34 селищ ), її щільність є нижчою від середньоукр їнських зн чень і т к с мо нижчою від щільності міст, як є однією з н йвищих в кр їні. і дв чинники зумовили зн чно менший, ніж у середньому по кр їні, рівень функціон льної зн чущості селищ ьвівської обл. в обслуговув нні сільської місцевості. е підтверджене і тим ф ктом, 
що лише в одній ьвівській обл сті жодне селище не є центром дміністр тивного p йону. скільки доволі зн чн кількість міських поселень обл сті розміщен в меж х гломер цій, то у відд лених від них р йон х зн чення селищної мережі зрост є. е особливо стосується двох гірських р йонів - колівського т урківського, т кож північно-східних - олочівського, родівського, дехівського, де порівняно менш щільність міських поселень з г лом.

иділення у меж х усієї ьвівської обл. сіл (т бл. 2), для яких селищ є н йближче розміщеними у цьому р йоні міськими поселеннями (не розгляд лися селищ рюхови-

блиця 2

ількість сільських поселень т сільського н селення ьвівської обл., для яких ці селищ $є$ н йближче розміщеними міськими поселеннями

\begin{tabular}{|c|c|c|}
\hline елищ & $\begin{array}{c}\text { ількість сіл, для яких це } \\
\text { селище є н йближче } \\
\text { розміщеним міським } \\
\text { поселенням }\end{array}$ & $\begin{array}{c}\text { ількість сільського } \\
\text { н селення, для якого це } \\
\text { селище є н йближче } \\
\text { розміщеним міським } \\
\text { поселенням } \\
\end{array}$ \\
\hline ориня & 29 & 17929 \\
\hline еликий юбінь & 12 & 4191 \\
\hline ерхнє иньовидне & 12 & 9782 \\
\hline ірник & - & - \\
\hline ніздичів & 5 & 2810 \\
\hline ш в & 11 & 7563 \\
\hline обротвір & 18 & 4914 \\
\hline убляни & 8 & 2398 \\
\hline вирк & 1 & 1134 \\
\hline ур вно & 30 & 13025 \\
\hline питів & 2 & 1671 \\
\hline в но- р нкове & 13 & 7833 \\
\hline p ковець & 9 & 4280 \\
\hline p сне & 10 & 6776 \\
\hline уликів & 14 & 6787 \\
\hline оп тин & 13 & 5479 \\
\hline герів & 18 & 7050 \\
\hline еденичі & 7 & 5965 \\
\hline емирів & 18 & 5379 \\
\hline иж нковичі & 16 & 5925 \\
\hline овий ричів & 10 & 7004 \\
\hline ові трілищ & 17 & 4840 \\
\hline лесько & 14 & 4738 \\
\hline ідбуж & 5 & 4570 \\
\hline ідк мінь & 28 & 9570 \\
\hline оморяни & 8 & 1498 \\
\hline озділ & 5 & 5886 \\
\hline л вське & 18 & 13680 \\
\hline т $\mathrm{p}$ іль & 7 & 2888 \\
\hline хідниця & 13 & 5502 \\
\hline кло & 4 & 3840 \\
\hline ирець & 16 & 5432 \\
\hline
\end{tabular}


чі т удно, які ф ктично ст ли структурними одиницями м. ьвов ), з свідчило, що для пон д $21 \%$ всіх сільських поселень і пон д $12 \%$ усього сільського н селення регіону с ме селищ є центр льними місцями у з безпеченні первинних соці льних послуг. йбільші позиційні можливості для обслуговув ння сільської місцевості м ють селищ, розміщені н зн чній відст ні від ядр ьвівської гломер ції, - ориня ( урківський р-н), ерхнє иньовидне, л вське ( колівський р-н), ідк мінь ( родівський р-н), ур вно ( ид чівський р-н). одноч с треб виділити і кільк селищ, розміщених відносно ближче до геогр фічного центру обл сті, які т кож м ють передумови центр льного геогр фічного розт шув ння щодо зн чної кількості сільських поселень.

е н с мперед стосується селищ в но- р нкове, герів, овий ричів, уликів, p сне, ирець, які до реформи р йонного дміністр тивного поділу, що відбул ся н прикінці 50-х років ст., виконув ли функції р йонних центрів. н чний р діус впливу у сільській місцевості х р ктерний т кож для селищ иж нковичі, емирів, еденичі. плив селищ хідниця дещо нівельов ний впливом усієї рогобицько- орисл вської гломер ції.

іст влення р діусів впливу селищ міського типу у сільській місцевості з деякими особливостями їхнього інфр структурного з безпечення т геогр фічного положення щодо шляхів сполучення з свідчує у деяких вип дк х недост тність їхніх інфр структурного т позиційного потенці лів для якісного викон ння функцій обслуговув ння.

е н йбільше стосується селищ ориня, ідк мінь, оморяни, які, з одного боку, м ють потенційні можливості ст ти лок льними центр ми обслуговув ння зн чної 3 площею сільської місцевості, 3 іншого, - 3 всім п р метр ми є сьогодні яскр во вир женими депресивними поселеннями, що виявляється й у зниженні їхньої людності [4, с. 12]. ому под льше погіршення соці льно-економічного ст новищ цих селищ нег тивно позн читься і н соці льному розвитку прилеглої сільської місцевості. одноч с у процесі розвитку туризму т рекре ційного господ рств ост нніми рок ми поліпшилися суспільно-геогр фічні передумови для викон ння центр льно-орг ніз ційних соці льних функцій селищ ми л вське т ерхнє иньовидне, що є одним 3 позитивних моментів в ктивіз ції соці льно-економічного життя гірського колівського р-ну з г лом.

с мкінець з зн чимо, що визн чення ролі селищ міського типу в обслуговув нні сільської місцевості може слугув ти своєрідним інформ ційним орієнтиром у здійсненні регіон льної екістичної політики, спрямов ної н зміцнення як селищної мережі, т к і сільського розселення.

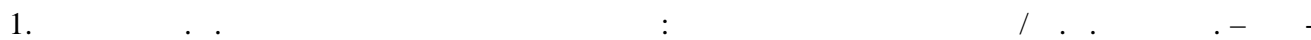
нівці: ут , 2003. - 392 с.

2. оценко . . ериторі льн орг ніз ція розселення (теорія т пр ктик ) / . . оценко. - . : енікс, 2010. - $536 \mathrm{c}$.

3. оценко .. труктурні н прями соці льно-економічного розвитку селищ міського типу уг нської обл сті в умов х ринкової тр нсформ ції / . . оценко, . . в рік // егіон - 2010: стр тегія оптим льного розвитку. - . : імені . . p зін , 2010. - .27-30.

4. ількість н селення ьвівської обл сті : ст тист. зб. ьвів : оловне упр вління ст тистики у ьвівській обл сті. - ьвів, 2010. - 70 с. 


\section{ROLE OF URBAN TYPE SETTLEMENTS OF LVIV REGION IN SOCIAL MAINTENANCE OF RURAL LOCALITY}

\section{N. Dnistryanska}

Ivan Franko National University of Lviv, . Doroshenko St., 41, UA - 79000 Lviv, Ukraine

Method of analysis of social-geographical role of settlements in social maintenance of rural locality have been argued. The demographic contours of sphere of influence of settlements in rural locality of Lviv Region are marked and functional possibilities of settlements are analysed in social-geographical aspect.

Key words: settlements of urban type, rural locality, social maintenance, demographic potential.

\section{- нистрянск я}

ввовский н цион льный университет имени в н р нко,

ул. . орошенко, 41, г. ввов, 79000, кр ин

боснов но методику н лиз общественно-геогр фической роли поселков в соци льном обслужив нии сельской местности. бозн чено демогр фические контуры сферы влияния поселков ьвовской обл. н сельскую местность и про н лизиров но функцион льные возможности поселков в общественно-геогр фическом спекте.

лючевые слов : поселки городского тип, сельск я местность, соци льное обслужив ние, демогр фический потенци л поселков. 